\title{
Pojale (Ketela Pohon Jagung dan Kedelai) sebagai Bahan Pengembangan Beras Analog Pengendali Kegemukan
}

\author{
The Development of Analog Rice as Obesity Control from Pojale Materials (Cassava, \\ Corn and Soybean)
}

\author{
Sukamto Sukamto ${ }^{1 *}$, Moh Sui $^{1}$, Sudiyono Sudiyono ${ }^{1}$,Patria Domas $G^{2}$, Fatimah Karim ${ }^{3}$ \\ ${ }^{1}$ Fakultas Pertanian, Universitas Widyagama, Malang, Jawa Timur 65142 \\ ${ }^{2}$ Program Pascasarjana, Teknologi Pertanian, Universitas Brawijaya, Malang, \\ Jawa Timur 65145 \\ ${ }^{3}$ Departemen Seni Kuliner, Universitas Negeri Malang, Jawa Timur 65145 \\ ${ }^{*}$ Penulis untuk korespondensi: sukamuwg@yahoo.com
}

\begin{abstract}
Population growth can cause two problems, namely food shortage population and overweight and obese population. Indonesians who are overweight and obese have reached $25 \%$. This study aimed to develop analog rice which is used to control obesity from corn and cassava based ingredients containing high amylose, and soybeans as a protein source. The basic ingredients of corn flour, cassava flour and soy flour pass the 80 mesh sieve. In the analog rice granulation process, the Twin Screw Extruder KL Protecal machine was used. The temperature settings for the extruder thread at the beginning, middle and end are $80^{\circ} \mathrm{C}, 85^{\circ} \mathrm{C}$ and $90^{\circ} \mathrm{C}$, respectively. The results showed that the best composition of the ingredients of corn flour, cassava flour and soy flour is $1: 1: 0$ in terms of color, texture, structure and surface smoothness. The cooking time is 8-10 minutes, and the water added is 1.5 times of the analog rice. The protein component was $9.44 \%$, starch $76.40 \%$; fiber, $7.99 \%$ and amylose, $36 \%$ after the formula is added with $10 \%$ of soy flour. Sensory test results showed that panelists on average liked the taste of this analog rice.
\end{abstract}

Key words: analog rice, cassava, soybeans, corn, obesity

\begin{abstract}
ABSTRAK
Pertumbuhan penduduk dapat menimbulkan 2 permasalahan yaitu meningkatnya penduduk yang rawan pangan dan penduduk yang kegemukan dan obesitas. Penduduk Indonesia yang mengalami kegemukan dan obesitas telah mencapai $25 \%$. Penelitian ini bertujuan untuk mengembangkan beras analog yang difungsikan untuk pengendali kegemukan dari bahan dasar pojale yang mengandung amilosa tinggi. Bahan dasar tepung jagung, tepung singkong dan tepung kedelai lolos ayakan 80 mesh. Proses granulasi beras analog menggunakan Twin Screw Extruder KL Protecal. Pengaturan suhu pada ulir extruder bagian awal, tengah dan akhir masing-masing: $80^{\circ} \mathrm{C}, 85^{\circ} \mathrm{C}$ dan $90^{\circ} \mathrm{C}$. Hasil penelitian menunjukkan bahwa komposisi bahan tepung jagung, tepung singkong dan tepung kedelai 1:1:0 memberikan hasil terbaik dari aspek warna, tekstur, struktur dan kehalusan permukaan. Waktu tanak yang dibutuhkan 8-10 menit dan air yang ditambahkan 1,5 kali beras analog yang ditanak. Komponen nutrisi protein $9,44 \%$, pati $=76,40 \%$, serat 7,99\% dan amilosa 36\% setelah formula di tambah tepung kedelai $10 \%$. Hasil uji sensoris menunjukkan rata-rata panelis menyukai.
\end{abstract}

Kata kunci: beras analog, singkong, kedelai, jagung, kegemukan 


\section{PENDAHULUAN}

Penduduk Indonesia pada tahun 2017 mencapai hampir 262 juta jiwa, sebagian besar adalah usia produktif, jumlah penduduk usia tidak produktif terhadap penduduk produktif pada 2016 sebesar 48,4 persen (Katadata, 2018). Ditinjau dari pola konsumsi pangan pertumbuhan penduduk yang cukup besar juga menimbulkan 2 permasalahan antara lain meningkatnya jumlah penduduk yang kekurangan pangan/rawan pangan dan penduduk yang kelebihan konsumsi pangan sehingga menimbulkan kegemukan dan obesitas (Sukamto, 2018). Badan Pangan Dunia (FAO) menyatakan bahwa dari total 250 juta penduduk Indonesia masih terdapat $7,9 \%$ atau sekitar 20 juta penduduk yang kekurangan pangan yang tersebar di Nusa Tenggara Timur (NTT), Nusa Tenggara Barat (NTB), Papua Barat, dan Papua. Sementara sisanya berada di pulau-pulau kecil di Sumatera dan sebagian di pulau Jawa (Idris, 2016). Disisi lain terdapat penduduk yang kelebihan konsumsi pangan sehingga menimbulkan kegemukan dan obesitas. Rahmad (2017) melaporkan bahwa terdapat 2,2 miliar orang di seluruh dunia mengalami kelebihan berat badan. Jumlah penduduk di Indonesia yang telah mengalami kegemukan dan obesitas mencapai 25\% (Nandini, 2018). Indonesia berada di peringkat 10 di dunia Negara yang jumlah penduduknya terkena obesitas dan kegemukan (BBC, 2014).
Kebiasaan mengkonsumsi beras dari padi perlu segera dikurangi karena ketersediaan lahan untuk penanaman padi telah terjadi depresiasi yang cukup besar (Suswono, 2013). Disamping itu beras dari padi mengandung kalori yang relative tinggi ditambah dengan pola konsumsi yang berlebihan akan mendorong terjadinya kasus kegemukan dan obesitas yang lebih cepat. Beras analog dibuat dari bahanbahan lain non padi yang diformula kusus sehingga komponen nutrisinya dapat diatur sesuai dengan manfaat yang diinginkan. Ketela pohon (singkong) dan jagung adalah tanaman yang potensi sebagai sumber karbohidrat yang kaya akan amilosa dan serat, sedangkan kedelai adalah bahan pangan nabati yang dapat dipakai sebagai sumber protein. Beras analog yang diformula dari ketiga bahan tersebut sangat potensial sebagai bahan pangan pengendali kegemukan karena kadar amilosa dan seratnya relative tinggi. Penelitian ini bertujuan untuk pengembangan beras analog dari bahan dasar ketela pohon, jagung dan kedelai (pojale) yang dikususkan untuk masyarakat yang telah mengalami overweight dan obesitas.

\section{BAHAN DAN METODE}

\section{Formulasi Bahan}

Penyedian tepung untuk menyusun beras analog terdiri dari tepung ubikayu, tepung jagung, dan tepung kedelai. Formula bahan pada masing-masing perlakuan (Tabel 1).

Tabel 1. Formula beras analog dari bahan dasar tepung ubikayu, tepung jagung, dan tepung kedelai.

\begin{tabular}{lcc}
\hline \multicolumn{1}{c}{ Bahan Tepung } & $\begin{array}{c}\text { Formula dengan Tepung } \\
\text { Kedelai }\end{array}$ & $\begin{array}{c}\text { Formula Tanpa Tepung } \\
\text { Kedelai }\end{array}$ \\
\hline Ubi kayu & 4,5 & 5,0 \\
Jagung & 4,5 & 5,0 \\
Kedelai & 1,0 & 0 \\
\hline Jumlah & 10 & 10 \\
\hline
\end{tabular}

Masing formula ditambah minyak goreng $250 \mathrm{~g}$, garam dapur $50 \mathrm{~g}$, gliserol mono stearat $25 \mathrm{~g}$, Na. Alginat 25g dan STPP $25 \mathrm{~g}$ tiap $10 \mathrm{~kg}$ bahan. 


\section{Proses extrusi formula beras analog}

Formula bahan yang sudah dipersiapkan diekstrusi dengan menggunakan Twin screw extruder KL Protecal di CV. Wijaya Food Kabupaten Blitar. Formula bahan sebanyak $10 \mathrm{~kg}$ dicampur dalam dry mixer selama 10 menit dan ditambah, minyak, garam, gliserol mono stearat dan Na. Alginat dan Sodium Three Poly Phosphate (STTP) dalam jumlah yang tetap dalam proporsi formula adonan. Ekstrusi pada temperatur ujung, tengah dan akhir masing-masing : $80^{\circ} \mathrm{C}$, $85^{\circ} \mathrm{C}$ dan $90^{\circ} \mathrm{C}$. Kecepatan ulir dalam extruder $40 \mathrm{~Hz}$ dan kecepatan pemotongan $20 \mathrm{~Hz}$. Butiran beras analog yang keluar dari extruder dikeringkan sampai kadar air $\pm 10 \%$. Pengamatan dilakukan terhadap bentuk dan ukuran beras analog, sifat fisik, komposisi kimia dan sifat sensoris.

\section{HASIL DAN PEMBAHASAN}

\section{Bentuk dan Ukuran Beras analog}

Beras analog dari bahan yang berbeda setelah ekstrusi sudah menyerupai beras. Panjang 5,7 $\pm 0,2 \mathrm{~mm}$ dan diameter $1,0 \pm 0,15 \mathrm{~mm}$, dimana ujungnya berbentuk lancip. Perrmukaan masih lebih kasar dibandingkan beras dari padi, selengkapnya seperti pada Gambar 1.
F0

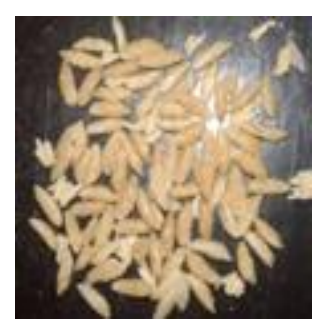

F1

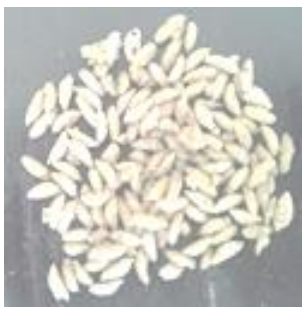

Rice

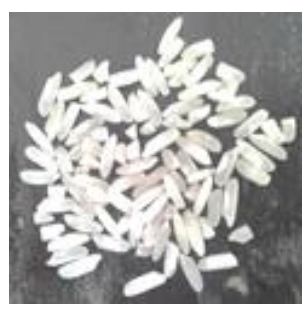

Gambar 1. Bentuk dan ukuran beras analog dari bahan dasar yang berbeda setelah extrusi. F0 : Formula tanpa tepung kedelai. F1 : Formula ditambah tepung kedelai.

Ukuran beras analog tergantung dari ukuran slit die dari mesin extruder yang digunakan. Bobot 100 butir, kerapatan curah, waktu tanak dan rasio ekspansi dari beras analog pada masing-masing perlakuan (Tabel 2).

Tabel 2. Sifat fisik dari beras analog dari bahan dasar pojale

\begin{tabular}{|c|c|c|c|c|c|}
\hline No & Formula & $\begin{array}{l}\text { Bobot } 100 \text { Butir } \\
\text { (G) }\end{array}$ & $\begin{array}{l}\text { Kerapatan } \\
\text { Curah (G/Ml) }\end{array}$ & $\begin{array}{l}\text { Waktu } \\
\text { Tanak (Menit) }\end{array}$ & $\begin{array}{l}\text { Rasio } \\
\text { Ekspansi }\end{array}$ \\
\hline 1 & $\begin{array}{l}\text { Formula } 0 \\
\text { (tanpa kedelai) }\end{array}$ & 0,30 & 0,50 & $8-10$ & 2,5 \\
\hline 2 & $\begin{array}{l}\text { Formula } 1 \\
(+10 \% \text { Kedelai })\end{array}$ & 0,32 & 0,51 & $11-13$ & 2,55 \\
\hline 3 & Beras biasa & 0,33 & 0,55 & 30 & 3,20 \\
\hline
\end{tabular}

Bobot 100 butir menunjukkan bobot tiap butir beras formula sehingga dapat menentukan berat hasil produksi. Data pada Tabel 2. menunjukkan bahwa bobot per 100 butir antara beras analog rata-rata lebih rendah dibandingkan dengan beras padi.
Bobot per 100 butir dari beras analog sangat dipengaruhi oleh struktur, rongga udara dan kadar air. Bobot beras analog yang ditambah tepung kedelai lebih tinggi dibandingkan dengan yang tanpa ditambah tepung kedelai. Hal ini diduga karena 
terjadinya interaksi komponen protein, lemak dan karbohidrat yang lebih kompak sehingga membentuk struktur yang lebih padat.

\section{Kerapatan curah (bulk density)}

Kerapatan curah (bulk density) merupakan kerapatan bahan curah dalam keadaan volume seimbang. Tabel 2 menunjukan kerapatan curah beras analog tanpa ditambah tepung kedelai lebih rendah dibandingkan dengan yang tanpa ditambah tepung kedelai. Menurut Setiawati dkk. (2014) besarnya kerapatan curah berpengaruh terhadap tempat yang dibutuhkan untuk bahan tersebut. Semakin besar kerapatan curah (partikel), maka semakin kecil tempat yang dibutuhkan, begitupun sebaliknya.

\section{Cooking time}

Cooking time merupakan waktu yang digunakan untuk memasak beras analog hingga didapatkan beras yang matang sempurna. Cooking time dalam penelitian beras analog adalah $8-13$ menit (Tabel 2). Waktu tanak beras analog tersebut jauh lebih singkat disbanding beras biasa. Cooking time pada produk beras formula sangat dipengaruhi oleh tingkat gelatinisasi bahan yang digunakan. Semakin tinggi tingkat gelatinisasinya maka nilai cooking time beras analog akan semakin lama. Temperatur gelanitinisasi pati sangat tergantung pada sumber bahan baku penyusunnya. Makin tinggi kandungan amilosa, kemampuan pati untuk menyerap air dan mengembang menjadi lebih besar karena amilosa mempunyai kemampuan membentuk ikatan hidrogen yang lebih besar daripada amilopektin.

\section{Ekspansi rasio}

Ekspansi rasio menggambarkan kemampuan beras formula dalam mengembang akibat dari pengaruh penggunaan air dan pemasakan. Hasil pengujian menggunakan air $1,5 \mathrm{X}$ berat beras analog, rasio ekspansi mencapai 3,25 pada beras analog tanpa penambahan tepung kedelai. Pengembangan beras analog yang ditambah tepung kedelai lebih rendah karena pengaruh serat yang terkandung didalamnya. Kondisi tersebut terjadi karena tepung kedelai ditepung bersama kulitnya. Beras analog sesudah ditanak dapat dilihat pada Gambar 2.
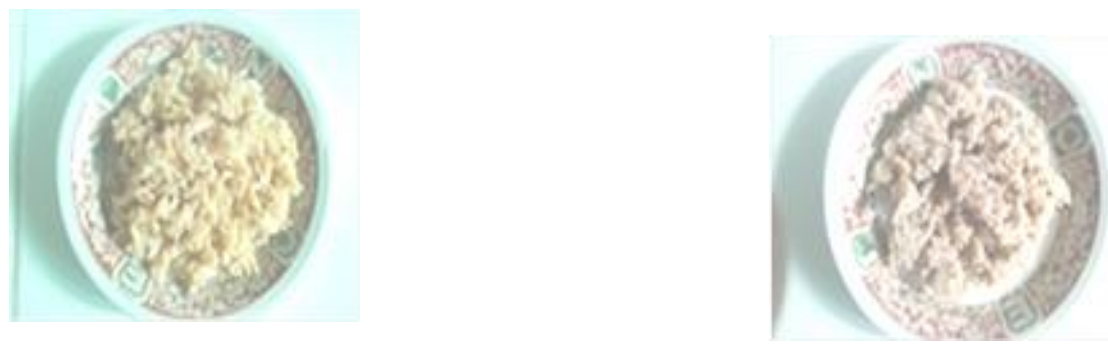

Gambar 2. Pengembangan beras analog sesudah ditanak, rasio beras formula dengan air 1: 1,5. (A) tanpa tepung kedelai, (B) dengan tepung kedelai $10 \%$.

\section{Komponen Kimia}

Penambahan tepung kedelai dalam formula beras analog dimaksudkan untuk meningkatkan jumlah protein. Hasil penelitian penambahan tepung kedelai $10 \%$ dalam formula beras analog terhadap perubahan komponen kimia beras analaog dari bahan bahan baku tepung singkong dan tepung jagung (Tabel 3). 
Tabel 3. Pengaruh penambahan tepung kedelai dalam beras analog dari bahan dasar tepung singkong dan jagung pada komponen kimianya.

\begin{tabular}{llccc}
\hline No & Komponen & $\begin{array}{c}\text { Tanpa Penambahan } \\
\text { Tepung Kedelai }\end{array}$ & $\begin{array}{c}\text { Penambahan Tepung } \\
\text { Kedelai } 10 \%\end{array}$ & $\begin{array}{c}\text { Beras Biasa } \\
* *)\end{array}$ \\
\hline 1 & Air $(\mathrm{g} / 100 \mathrm{~g})$ & 11,9 & 14,00 & 11,62 \\
2 & Protein $(\mathrm{g} / 100 \mathrm{~g})$ & 4,2 & 9,44 & 7,13 \\
3 & Lemak $(\mathrm{g} / 100 \mathrm{~g})$ & 0,90 & 2,90 & 0,66 \\
4 & Serat $(\mathrm{g} / 100 \mathrm{~g})$ & 7,71 & 7,99 & 0,12 \\
5 & Pati $(\mathrm{g} / 100 \mathrm{~g})$ & 80,55 & 76,40 & 90 \\
6 & Amilosa $(\mathrm{g} / 100 \mathrm{~g})$ & 36,93 & 36,00 & 17 \\
7 & Abu $(\mathrm{g} / 100 \mathrm{~g})$ & 0,55 & 0,72 & 0,8 \\
8 & Ca(mg/100g) & 30,00 & 27,00 & 28,00 \\
9 & P (mg/100g) & 80,0 & 19,00 & 115,00 \\
\hline
\end{tabular}

Keterangan :*) data berasal dari 3 kali ulangan

\section{Kadar air}

Kadar air beras analog yang komponen bahannya ditambah tepung kedelai lebih tinggi dibandingkan dengan yang tanpa ditambah tepung kedelai (Tabel 3). Kadar air yang didapat sudah mendekati kadar air beras giling $(11,62 \mathrm{~g} / 100 \mathrm{~g})$. Kadar air beras analog yang diproses dengan Extruder sangat dipengaruhi oleh formula awal, pemanasan saat granulasi dan pengeringan setelah proses granulasi.

\section{Kadar Protein}

Kadar Protein Kadar protein beras analog yang ditambah tepung kedelai mencapai 9,44\% lebih tinggi dibandingkan yang tanpa penambahan tepung kedelai maupun beras biasa. Hasil tersebut menunjukkan bahwa beras analog yang diformula dari tepung ubi kayu dan tepung jagung, tepung kedelai kadar proteinnya lebih tinggi dari beras padi yaitu 6,81 g/100g (USDA, 2011 ). Kadar protein yang rendah pada beras analog yang diformula dari bahan dasar tepung ubi kayu dengan tepung jagung sekitar 4,2\%. Kondisi ini terjadi karena kadar protein beras analog berbanding lurus dengan kadar protein bahan dasar yang digunakan. Tepung ubi kayu dan tepung jagung mengandung protein yang relatih rendah sehingga kadar protein beras analog yang dihasilkan juga rendah. Akdogan (1999) menyatakan bahwa kadar protein dari beras formula sangat dipengaruhi oleh kondisi operasi extruder dan bahan formula yang digunakan. Alsaffar (2011) menjelaskan bahwa keberadaan protein dalam formula beras analog berfungsi untuk menurunkan respon glikemik karena protein dapat memperlama laju aliran makanan dalam lambung sehingga kecepatan absorbsi dan pencernaan dalam usus halus menjadi lebih lambat. Kondisi tersebut secara tidak langsung dapat mengendalikan kegemukan.

\section{Kadar Lemak}

Kadar Lemak beras analog tanpa penambahan tepung kedelai sangat rendah yaitu $0,9 \%$, sedangkan beras analog yang ditambahan dengan teoung kedelai lemaknya naik menjadi 2,9\%. Hasil tersebut disebabkan oleh tepung kedelai mengandung lemak tinggi sekitar 20\%. Beras analog yang dihasilkan (Tabel 3) mengandung kadar lemak lebih tinggi dari kadar lemak beras biasa yaitu $0,55 \mathrm{~g} / 100 \mathrm{~g}$ (USDA, 2011 ). Kadar lemak yang lebih tinggi pada beras formula akibat dari penambahan lemak saat proses produksi. Keberadaan lemak tersebut sangat diperlukan untuk menghindari tingkat kelengketan dan kehalusan produk akhir. Lemak dapat mengurangi gaya friksi antar partikel dan antara permukaan screw dan barrel (Budi, Hariyadi, Budijanto dan Syah, 2013). Kondisi tersebut dapat memperbaiki kehalusan permukaan beras analog.

\section{Kadar Pati dan Amilosa}

Kadar Pati dan Amilosa dari beras analog yang ditambah maupun yang tidak ditambah tepung kedelai mengandung 
amilosa yang relative tinggi. Hal ini memang dikehendaki karena beras analog diformula dari bahan-bahan yang mengandung amilosa tinggi. Kadar amilosa tertinggi adalah $36,9 \mathrm{~g} / 100 \mathrm{~g}$ sedangkan beras biasa mengandung amilosa sekitar 17 g/100g. Budijanto dan Yuliyanti (2012) menjelaskan bahwa amilosa dan amilopektin berpengaruh pada tekstur beras padi maupun beras analog setelah ditanak. Menurut Yusof et al. (2005), beras yang mengandung amilosa yang tinggi akan menghasilkan nasi pera dan tekstur keras setelah dingin, sedangkan beras yang mengandung amilopektin yang tinggi akan menghasilkan nasi yang pulen dan tekstur yang lunak. Kadar amilosa dari bahan baku berhubungan dengan tingkat penerimaan konsumen dan mempengaruhi proses pemasakan (Qi et al. 2010). Namun demikian dalam proses produksi ditambahkan Na-Alginat dan tepung kedelai dalam jumlah yang tetap dalam formula sehingga mampu mempengaruhi tekstur setelah tanak.

\section{Kadar Serat}

Kadar serat dari beras analog (Tabel

3) yang diformula dengan ditambah maupun tanpa ditambah tepung kedelai mengandung serat yang relatif tinggi. Hal ini memang dikehendaki karena beras formula yang diproduksi difungsikan sebagai produk pangan fungsional pengendali kegemukan. Kadar serat yang relatif tinggi juga dapat berperan dalam memperbaiki sistem pencernaan. Kadar serat tertinggi adalah 7,99g/100g pada beras analog yang ditambah tepung kedelai, sedangkan yang tidak ditambah tepung kedelai kadar seratnya 7,71 g/100g. Pada beras analog yang ditambah tepung kedelai kadar seratnya lebih tinggi karena tepung kedelai yang digunakan digiling bersama kulitnya.

\section{Sensoris}

Hasil uji sensoris warna yang menggunakan 10 panelis menunjukkan beras analog tanpa penambahan tepung kedelai lebih disukai mulai angka 5 sampai 7 yaitu disukai sampai sangat disukai. Walaupun demmikian jika dilhat dari derajad keputihan masih dibawah beras biasa. Berdasarkan penilaian panelis pada kesukaan warna masih sangat dipengaruhi oleh kebiasaan melihat dan mengkonsumsi beras dari padi. Sehingga secara keseluruhan skor yang didapat adalah 5,8, dan skor tersebut masih lebih rendah dari skor warna dari beras biasa. Perbedaan warna dibanding dengan beras biasa disebabkan karena beras analog dibuat dari bahan dasar non beras yang warna awalnya sudah tidak putih seperti beras biasa, disamping itu juga terjadinya reaksi Millard akibat interaksi protein dengan karbohidrat.

Hasil uji tekstur menggunakan 10 panelis menunjukkan beras analog menunjukkan angka 4 sampai 5 yaitu agak disukai sampai disukai. Tekstur lebih disukai pada beras analog tanpa penambahan tepung kedelai dengan skor rata-rata 5 .

Hasil uji aroma menunjukkan angka 4 sampai 5 yaitu disukai, namun jika dibandingkan aroma nasi dari beras biasa masih mendapatkan skor yang lebih rendah. Tekstur, rasa dan aroma dari nasi dari beras analog dipengaruhi dari bahan dasarnya, sementara panelis sudah terbiasa mengkonsumsi nasi dari beras biasa. Kondisi tersebut diduga yang menyebabkan hasil uji sensori rata-rata masih lebih kecil dari beras padi.

\section{KESIMPULAN}

Berdasarkan hasil penelitian dapat disimpulkan hal-hal sebagai berikut: Bahan baku lokal seperti ubi kayu dan jagung dapat digunakan sebagai bahan baku utama dan berperan sebagai sumber karbohidrat kususnya pati resisten dalam produksi beras analog pengendali kegemukan. Sementara tepung kedelai digunakan sebagai sumber protein nabati.

Sodium Three Poly Phosphat (STPP), Na Alginat, GMS, garam dapur digunakan sebagai binding agent serta 
membantu dalam homogenitas serta distribusi air yang lebih merata dalam adonan sebelum diekstrusi dalam extruder. Komopsisi nilai gizi rata-rata lebih tinggi dari pada beras biasa terutama kadar protein, lemak, serat, dan amilosa. Warna beras formula antikegemukan tidak berwarna putih sebagaimana pada

beras biasa karena bahan baku awal mempunyai warna yang bervariasi.

Sifat fisik khususnya rasio ekspasi (kemampuan mengembang) yang tertinggi didapatkan pada formula utama tepung ubi kayu yang dicampur dengan tepung jagung tanpa tepung kedelai yaitu 2,95. Penggunaan air saat menanak $1,5 \mathrm{ml} \mathrm{ml}$ per gram beras formula, waktu tanak hanya 6-9 menit.

Derajad kesukaan terhadap warna, rasa, aroma dan tekstur rata-rata menyukai sampai sangat menyukai,walupun masih lebih rendah dari pada beras biasa.

\section{UCAPAN TERIMA KASIH}

Ucapan terima kasih disampaikan pada Direktorat Riset dan Pengabdian kepada Masyarakat, Kementerian Riset Teknologi dan Pendidikan Tinggi Republik Indonesia yang memberikan dukungan dana dalam penelitian.

\section{DAFTAR PUSTAKA}

Akdogan H. 1999. High moisture food extrusion. Int. J. Food Sci. Tech. 34: 195-207.

Alsaffar AA. 2011. Effect of food processing on the resistant starch content of cereals and cereals products - a review. Int. J. Food Sci. Tech. 46: 455-462.

BBC. 2014. Tingkat obesitas Indonesia nomor 10 dunia. https://www.bbc.com/ Indonesia [Diakses 9 September 2018].

Budi FS, Hariyadi P, Budijanto S dan Syah D. 2013. Teknologi Proses Ekstrusi untuk Membuat Beras Analog. PANGAN, 22 (3) : 263-274.
Budijanto S, Yuliyanti. 2012. Studi persiapan tepung sorgum (Sorghum bicolor L. Moench) dan aplikasinya pada pembuatan beras analog. $J$ Teknol. Pert. 13: 177-186.

Idris M. 2016. Dua puluh juta orang di RI kekurangan konsumsi pangan. Https://finance.detik. com wawancarakhusus/d-3317515. [Diakses 9 September 2018].

Katadata. 2018. Jumlah Penduduk Indonesia Mencapai 265 Juta Jiwa. https://databoks.katadata.co.id/..[Dia kses 9 September 2018].

Rahmad A. 2017. 2,2 miliar penduduk dunia alami obesitas. Https://netz.id/ news/2017/06/18/00416 [Diakses 9 September 2018].

Nandini W. 2018. 1 dari 4 penduduk dewasa mengalami obesitas. Https://katadata.co.id/ infografik/2018 [Diakses 9 September 2018].

Suswono. 2013. Penyusutan Lahan Sawah 100.000 Hektare Pertahun. Citra Indonesia Com. Jakarta.

Sukamto, Sui M, Sudiyono \& Figih HP. 2017. Food development potential for anti-obesity in supporting National food security P 74-86. In Khamelda, et al. (Edt.). $1^{\text {st }}$ Widya Karya International Seminar Proceedings Philosophy and Spirituality of higher education , ${ }^{5 \text { th }}$ November, 2016. Universitas Katolik Widya Karya. Malang.

Sukamto. 2018. Produksi dan pengembangan beras analog sebagai bahan makanan pokok nasional masa depan. Didalam Setiawidayat, dkk. (eds.), Inovasi Ipteks untuk mendukung pembangunan berkelanjutan. Proceeding The 1st Conference on Innovation and Application of Science and Technology. 12 September 2018. Universitas Widyagama Malang.

Setiawati N P, Santoso J, Purwaningsih S. 2014. Karakteristik Beras Tiruan dengan 
Penambahan Rumput Laut Yusof BNM, Talib RA, and Karim NA. Eucheuma Cottoniisebagai Sumber Serat Pangan. J.Vl.Tek.Kelautan 2005. Glycemic Index of Eight Types of Commercial Rice. Tropis. 6(1): 197-208. Malaysia J. Nutr. 11(2):151-1. 